\title{
POPULATION SITUATION AND TRENDS IN BALTIC COUNTRIES
}

\author{
Tamara Lukić ${ }^{* 1}$, Jelena Dunjić*, Bojan Đerčan*, Milica Solarevićc*, Sanja Božićc* \\ " University of Novi Sad, Faculty of Sciences, Departament of Geography, Tourism \\ and Hotel Management, Novi Sad
}

\begin{abstract}
The aim of this article is to study population situation and trends within the Baltic countries, exactly to say in Estonia, Latvia and Lithuania. The main objective is to find out if political changes during new history (such as the situation during disintegration of SSSR, getting the independence, joining to EU and staying in it), had influence on population situation in the Baltic countries. Other assignments in this work refer to mutual comparison of population indicators and establishing of similarities and differences among the Baltic countries. They are initiated by facts that these countries have similar physical geographical characteristics and social historical context during new history, but different size of population and ethnogenetic origin. Part of this work tells us about projections of inhabitants given till the year 2100. The results of the research are got by using analytic and synthetic method for data interpreting which are found at official demographic publications. The main contribution of this work is to expand knowledge about population in the Baltic countries in order to complete the picture about demographic characteristics of the European region within 20th into 21st century. The results of the research show that there are more similarities between Latvia and Estonia comparing with populous Lithuania.
\end{abstract}

Keywords: Estonia, Latvia, Lithuania demographic indicators, population situation, Baltic countries.

1 Corresponding author: T. Lukić, University of Novi Sad, Faculty of Sciences, Departament of Geography, Tourism and Hotel Management, Novi Sad;

e-mail: tamara.kovacevic@dgt.uns.ac.rs 


\section{Introduction}

This article is a part of expanded research of demographic changes in the European area. It is initiated by absence of adequate literature, in order to contribute to familiarization of the circumstances in the area of the Baltic countries. Although, in geographic sense, the Baltic sea is splashing the coasts of Denmark, Sweden, Finland, Germany, Russia, and Poland, in this case, under the term of the Baltic countries we consider republics of former Soviet Union: Estonia, Latvia and Lithuania. The most of the demographic literature such as Bowring (2015) mostly refer to relationships among ethnic groups, while concrete population parameters are hardly seen. The research of population of the Baltic countries was inspired by their geographic position and great geopolitical changes which they have undergone during last three decades: situation before SSSR disintegration, getting the independence in the year 1991, joining the European Union on 2004 (Lane, 2014; Smith, 2016; Hiden and Salmon, 2014; Šabić and Vujadinović, 2014; 2017; Vujadinović and Šabić, 2017) and staying in it. They are between Slavic East where they belong in the recent history and the countries of the European Union which surround them on other cardinal points. Last census in all Baltic countries was conducted in 2011. They were settled by small number of the Baltic people. The Estonians belong to Baltic-Finland group, but the Latvians and Lithuanians belong to the Baltic group of people. Official languages are: Estonian, Latvian and Lithuanian.

\section{Methods}

In this paper official data about variables of population policy and demographic indicators published by the United Nations $(2013,2015)$ were used, as well as the results of similar research so far. They were processed by analytic and synthetic methods and interpreted at the end. Variables refer on the last three and half decades. They are compared among the Baltic countries. Each one is considered separately, but their interdependence was considered as well, how much they can influence each other.

\section{Results and discussion}

The Baltic countries cover the area of $175,015 \mathrm{~km}^{2}$. According to estimation from the year 2016, there were 6,121,000 inhabitants. The Baltic countries are members of European Union, NATO and Euro-zone. Estonia is also the member of Organization for economic cooperation and development (OECD). 


\section{Population growth}

Marcu (2011) studied population of the EU countries in period from 2008 to 2010.Her conclusions show that population of Estonia has grown during those three years thanks to changes in natural movement of population while in other Baltic countries it declines. Estonia's growth was symbolic. Natural increase in population, net migration and total changes of population were on so-called "positive zero". Among causes for declined number of inhabitants in Lithuania she pointed out migrations, while for Latvia she stated that the most decisive was negative natural increase of population. According to Kazlauskiene and others (2015) inhabitants of Latvia declined during last twenty years because of negative natural increase of population and high emigration rate.

Analyzing the number of inhabitants during the last three decades the reduction trend was noticed. Data from 1995 show negative growth rates (Table 1). According to the United Nations (2015), from 2015 to 2050, population decrease of more than $15 \%$ is expected in eleven European countries. Lithuania $(17,5 \%)$ and Latvia $(19,1 \%)$ are among them. Estonian decrease is expected to be $14 \%$.

\section{Population density of the Baltic countries}

The Baltic countries are rarely settled. Population density varies between 28 inhabitants $/ \mathrm{km}^{2}$ (2011) in Estonia and 43 inhabitants $/ \mathrm{km}^{2}$ in Latvia which is $50 \%$ less in comparison with European continent average - 73 inhabitants $/ \mathrm{km}^{2}$ (2016). Population density has a tendency of reduction which is in accordance with variation in number of inhabitants. Regarding the fact that in 2013 population density in the European Union was 116 inhabitants per square kilometer according to Consilium (2014), it may be said that in Lithuania it was two and half times smaller, in Latvia three and half time but in Estonia four times smaller (Table 1).

Shares of urban population are mostly constant or slightly oscillate concerning value from the Soviet period. In comparison with value calculated for the European Union in 2016 of $75 \%$ of urban population (World Bank, 2018) it may be said that the Baltic countries aspire to it. Estonia has the greatest share of urban population (70\%) and Latvia has the least (67\%). Value share of urban population would be even bigger but the Baltic countries have negative population growth rate of urban population after getting their independency (Table 1).

Yearly growth rate of rural population has negative values during the whole observed period. The difference among Baltic countries appears in the share of this parameter in case of Lithuania they are increasing while in other countries they are reducing. 
Table 1. Population indicators in Baltic countries

\begin{tabular}{|c|c|c|c|c|c|c|c|c|c|c|c|c|c|c|}
\hline \multicolumn{3}{|l|}{ Indicators } & \multicolumn{3}{|c|}{1985.} & \multicolumn{3}{|c|}{1995.} & \multicolumn{3}{|c|}{2005.} & \multicolumn{3}{|c|}{2013.} \\
\hline \multicolumn{3}{|c|}{ States } & $\mathrm{LT}^{1}$ & $\mathrm{LA}^{2}$ & $\mathrm{EST}^{3}$ & LT & LA & EST & LT & LA & EST & LT & LA & EST \\
\hline \multirow{2}{*}{$\begin{array}{l}\text { Population size } \\
\text { and growth }\end{array}$} & \multicolumn{2}{|c|}{ Population size (thousands) } & 3564 & 2582 & 1522 & 3628 & 2488 & 1433 & 3287 & 2228 & 1325 & 3017 & 2050 & 1287 \\
\hline & \multicolumn{2}{|c|}{ Annual growth rate $(\%)$} & 0.75 & 0.54 & 0.64 & -0.38 & -1.37 & -1.77 & -1.25 & -1.25 & -0.61 & -0.46 & -0.57 & -0.28 \\
\hline \multirow{4}{*}{$\begin{array}{l}\text { Spatial } \\
\text { distribution }\end{array}$} & \multicolumn{2}{|c|}{ Population density (per sq. km.) } & 55 & 40 & 34 & 56 & 39 & 32 & 50 & 34 & 29 & 46 & 32 & 29 \\
\hline & \multicolumn{2}{|c|}{ Urban population (\%) } & 65 & 69 & 71 & 67 & 69 & 70 & 67 & 68 & 69 & 67 & 68 & 70 \\
\hline & \multicolumn{2}{|c|}{$\begin{array}{l}\text { Annual urban population growth } \\
\text { rate }(\%)\end{array}$} & 1.98 & 0.97 & 1.01 & -0.45 & -1.48 & -2.01 & -0.59 & -0.70 & -0.36 & -0.27 & -0.38 & 0.02 \\
\hline & \multicolumn{2}{|c|}{$\begin{array}{l}\text { Annual rural population growth } \\
\text { rate }(\%)\end{array}$} & -1.35 & -0.37 & $<0.01$ & -0.18 & -1.01 & -0.91 & -0.28 & -0.64 & -0.38 & -0.79 & -0.37 & -0.25 \\
\hline \multirow{4}{*}{$\begin{array}{l}\text { Population age } \\
\text { structure }\end{array}$} & \multicolumn{2}{|c|}{$\begin{array}{l}\text { Percentage of population under } \\
\text { age } 15\end{array}$} & 23 & 21 & 22 & 22 & 21 & 21 & 17 & 15 & 15 & 15 & 15 & 16 \\
\hline & \multicolumn{2}{|c|}{$\begin{array}{l}\text { Percentage of population aged } 60 \\
\text { or over }\end{array}$} & 15 & 17 & 16 & 17 & 19 & 19 & 20 & 23 & 22 & 21 & 24 & 24 \\
\hline & \multirow{2}{*}{$\begin{array}{l}\text { Statutory age at retirement } \\
\text { (years) }\end{array}$} & $\mathrm{M}$ & - & - & - & - & - & - & - & - & - & 62.5 & 62.0 & 63.0 \\
\hline & & $\mathrm{F}$ & - & - & - & - & - & - & - & - & - & 60.0 & 62.0 & 61.0 \\
\hline \multirow{3}{*}{$\begin{array}{l}\text { Health and } \\
\text { mortality }\end{array}$} & \multirow{3}{*}{$\begin{array}{l}\text { Life expectancy at birth } \\
\text { (years) }\end{array}$} & $\mathrm{T}$ & 70.5 & 69.1 & 69.3 & 69.7 & 67.7 & 68.5 & 71.6 & 70.7 & 71.3 & 72.1 & 72.1 & 74.3 \\
\hline & & $\mathrm{M}$ & 65.4 & 63.6 & 61.1 & 64.2 & 61.7 & 62.9 & 65.7 & 65.2 & 65.5 & 66.0 & 66.6 & 68.9 \\
\hline & & $\mathrm{F}$ & 75.5 & 74.2 & 74.2 & 75.3 & 73.7 & 74.1 & 77.5 & 76.2 & 77.0 & 78.1 & 77.5 & 79.5 \\
\hline Fertility & \multicolumn{2}{|l|}{$\begin{array}{l}\text { Total fertility (children per } \\
\text { woman) }\end{array}$} & 2.0 & 2.0 & 2.1 & 1.8 & 1.6 & 1.6 & 1.3 & 1.3 & 1.4 & 1.5 & 1.6 & 1.6 \\
\hline Family planning & \multicolumn{2}{|c|}{$\begin{array}{l}\text { Induced abortion rate (per } 1, p 00 \\
\text { women aged } 15-44 \text { ) }\end{array}$} & - & - & - & - & - & - & - & - & - & $9.8^{f}$ & $15.6^{c}$ & $25.5^{\mathrm{a}}$ \\
\hline \multirow[t]{5}{*}{$\begin{array}{l}\text { International } \\
\text { migration }\end{array}$} & \multicolumn{2}{|c|}{$\begin{array}{l}\text { International migrant stock } \\
\text { (thousands) }\end{array}$} & - & - & - & 349 & 646 & 382 & 212 & 430 & 250 & 148 & 283 & 210 \\
\hline & \multicolumn{2}{|l|}{$\begin{array}{l}\text { Percentage of females among } \\
\text { international migrants }\end{array}$} & - & - & - & 57 & 55 & 55 & 57 & 59 & 60 & 57 & 61 & 60 \\
\hline & \multicolumn{2}{|c|}{ Net migration rate (per thousand) } & 2.51 & 3.13 & 3.46 & -5.48 & -10.53 & -14.93 & -9.17 & -7.19 & -2.15 & -1.87 & -0.97 & 0.00 \\
\hline & \multicolumn{2}{|c|}{$\begin{array}{l}\text { Annual inflow of remittances in } \\
\text { US\$ (millions) }\end{array}$} & - & - & - & 1 & $41^{\mathrm{d}}$ & 1 & 534 & 381 & 264 & $1956 \mathrm{~g}$ & $695^{\mathrm{e}}$ & $407^{\mathrm{b}}$ \\
\hline & \multicolumn{2}{|c|}{$\begin{array}{l}\text { Annual inflow in US\$ (per } \\
\text { migrant) }\end{array}$} & - & - & - & - & - & - & 2518.9 & 886.0 & 1056.0 & 13216.2 & 2455.8 & 1938.1 \\
\hline
\end{tabular}

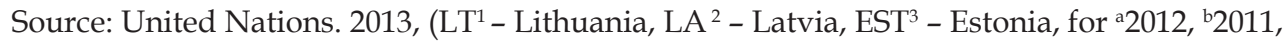
'2010, ${ }^{\mathrm{d}} 1996,{ }^{\mathrm{e}} 2011, \mathrm{f} 2010, \mathrm{~g} 2011$ )

\section{Indicators of the age structure}

Kalēja\& Mileiko (2016) write about age perception in Latvia according to information got from in-depth interviews but they do not state any numerical parameters for growing old. Data presented in the United Nations (2013) show that in all age structures of all Baltic countries share of population under 15 years reduces but population older than 60 years increases. However, the United Nations (2015) predict that share of inhabitants 0-14 years in the years 2050 and 2100 will keep the value of $15-16 \%$ according to middle variant, it will not be changed in comparison with actual values. Share of those who are older than 60 years will drastically increase in the Baltic countries. It is calculated for Lithuania that it will be increased from current $21 \%$ to $29,9 \%$ in 2050 , and to $31,7 \%$ in 2100 . The share of inhabitants older than 60 years in Latvia and Estonia should be increased from current $24 \%$. In 2050 Latvia is expected to have $33,1 \%$ of population older than 60 and in 2100 - 32,7\%, while in Estonia is foreseen 35\% for both years.

On the basis of calculated age index, the Baltic countries show greater mutual similarity regarding the period of census than some of them differes. Latvia has the youngest population. The highest increase of age index was be- 
tween census of 1995 and 2005. Entry of those countries within the borders of the European Union on 2004 motivated emigration of young people who were searching for a job, higher standard and quality of life. Therefore the inhabitants were growing old faster than it should have if there had not been emigration.

According to the criteria for age index identification given by Penev (1995), the Baltic countries were in the phase of demographic growing old before they became independent. The Lithuanians remained in that phase even after their independency, according to the census 1995, while the Latvians and Estonians have passed into the phase of deep demographic growing old. At the beginning of $21^{\text {st }}$ century, 2005, the Lithuanians came in the phase of deep demographic growing old while the Latvians and Estonians were in the phase of the deepest demographic growing old. Data from 2013 show that all of them were in the phase of the deepest demographic growing old (age index higher than 1,25). The values of age index are doubled in comparison with the time of Soviet authority. According to these conclusions, population of not numerous Latvians and Estonians were growing old faster than numerous Lithuanians, the Latvia's compatriots. According to projections by the United Nations (2015) for the year 2050 and 2100 and calculated values of age index higher than 2, all Baltic countries will remain in the phase of the deepest demographic growing old. The United Nations (2015) predict that according middle variant, 2050 medial age of the Estonians will be the highest $(45,9)$, then the Latvians $(45.3)$ and the Lithuanians $(44,3)$. In the year 2100 order of medial age should remain unchanged, but medial age will be increased: the Estonians $(47,4)$, the Latvians $(45,8)$, and the "youngest" Lithuanians $(45,0)$.

Those demographic changes will influence the authorities' calculation concerning tax collection, financial balancing in order to ensure adequate pensions and health protection. According to criteria for legal retirement age which are shown by the United Nations (2013) only for 2013, Latvia singles out because it is equal for both genders, 62 years. The women in Lithuania are retiring in the age 60, but in Estonia in 61. Men work 2 years longer. According to Puur and others (2015) at the beginning of nineties, after announcement of independency, it was found that the age limit for retirement of men is increased from 60 to 63 years and for women from 55 to 61 .

In 2010 the Baltic countries had bigger shares of the inhabitants older than 65 in comparison with the average of the European Union. It is calculated that from all countries of the European Union the biggest share of inhabitants older than 65 will have Latvia (35,7 \%) in 2060. According to Dixon \& Margo (2006), Estonia adopted demographic objectives or aspirations as the reply on the fact that its population is growing old. 


\section{Life expectancy}

According to data by Kazlauskiene (2015) and statistic office of the European Union, Eurostat, in 2010 the highest rates of mortality were calculated in Bulgaria $(14,6 \% \mathrm{o})$, Latvia $(13,4 \% \mathrm{o})$, Hungary $(13,0 \% \mathrm{o})$ and Lithuania $(12,8 \% \mathrm{o})$. According to same data the European Union had mortality rate of $9,7 \%$ o.Natural increase in population during the same period in the Baltic counties was between $-3,5 \% \mathrm{O}$ in Lithuania to $-4,5 \%$ o in Latvia.

Expected life duration is increasing from the independency in 1991 in all Baltic countries. United Nations (2013) data show that it is the largest in Estonia (74,3 years). The values of expected life duration in Lithuania and Latvia are almost the same (72,1 years) for the whole population, but concerning male inhabitants. Those values are less in comparison with calculated values for the European Union (80,9 years). According to the United Nations (2015) expected life duration in the Baltic countries will increase, so from 2045 to 2050 in Lithuania it will be 77,7, Latvia 78,0 and Estonia 81,7 years, and in the period 2095-2100, in Lithuania it will be 83,8, in Latvia - 84,2 and in Estonia - 87,4 years.

\section{Social implications of growing old}

Creighton (2014) gives the overview of the European countries per different demographic parameters and sporadically mentions extreme examples. According to his work, Baltic countries belong to the countries of the European Union which set aside minimum for social protection of old people, less than 500 Euro per person.

In all Baltic countries the pension amounts are less than $50 \%$ of the salary. For example, the Estonians expect to get pensions for quarter value of their salary and that is the minimal amount in comparison to all other countries of the European Union (OECD, 2012, Rajevska, 2015).

Population older than 65 years risk to become poor after social transfer retirement, because they get income less for $60 \%$ of the average salary. This leads toward material deprivation. For example, in 2012 it was calculated that $14 \%$ of population older than 65 was facing the risk of getting poor in European Union. Higher percentage than EU average was calculated for Lithuania (18\%), and Estonia (17\%) and lower for Latvia (11\%). Creighton (2014) wrote that in 2012, share of population older than 65 who felt material deprivation in all Baltic countries was higher than European Union average (17\%). In Latvia more than half people older than 65 felt it (50\%), in Lithuania more than two fifth (44\%) and in Estonia one fifth (20\%). However, in Estonia the pensions debit GDP with $8 \%$, which is the lowest percentage in the whole Union. As the growth of old population is expected, it is obvious that the share of financial resources needed 
for pensions, health protection, protection of old inhabitants will unavoidably grow too. Investigation show that on the average each fifth pensioner in Baltic countries complains on comfort of the apartment he lives in, on its warmth during winter etc.

\section{Fertility as indicator}

From the research the shares of population who enter in intermarriage could be seen (Lanzieri, 2012). The greatest shares of such population have Latvia $(20,7 \%)$, where on each fifth marriage comes one intermarriage, then Estonia $(15,8 \%)$ and minimum has Lithuania $(6,1 \%)$. Partnerships which are not in marriage alliance are not included. Marriage between the foreigners born in different countries do not belong to the item of intermarriage.

Given that for the simple renovation of generations, about 2,1 children per woman is needed (Đurđev, 2004), during the low mortality conditions, we may conclude that the Baltic countries did not even achieve the level of simple renovation of generations during the last three decades. The only data concerning fertility given by the United Nations (2013) refers to total fertility. The rates of total fertility do not differ mutually for more than 0,2 . They had the tendency of reduction till 2005, however according to the last available data they are increased for $0,2-0,3$ which means that in Lithuania were born 1,5 child per woman, while in other two countries 1,6 child per woman (Table 1). The United Nations (2015) predict that total fertility will start to grow in all Baltic countries after 2015. So, in middle variant, 2045-2050 their women will give a birth 1,8, but 2095-2100, 1,9 children per woman.

\section{Family planning}

The only numeric parameter concerning the family planning which is shown by the United Nations (2013) is inductive rate of abortions for women of age from 15 to 44 years. According to the stated, minimum value has the most numerous Lithuania $(9,8)$, while the inductive rate of abortions is two and half time higher in small population of Estonia $(25,5)$. Work on propaganda against abortion could contribute to maintain Estonian population.

\section{International migrations}

Data about migrants are given from the time when the Baltic countries became independent. The number of international migrants is getting less from decade to decade in all Baltic countries. The Latvians have the greatest number of international migrants. The share of women prevails and has a tendency to grow. Net rate of migration is negative since achieved independency but has 
tendency of reduction. In the first data upon getting the independency it was three and half times higher in Estonia in comparison to Lithuania (Table 1).

Baltic countries had intensive emigration of labor force during the first five years upon joining the European Union. According to Melnikas (2008), it was motivated by high rate of unemployment, inflation, low standard, joining the Eurozone. Reversible migrations appeared as the result of economic crisis during 2009-2010 (Galgóczi \& Leschke, 2016). Hazans (2016) noticed that lowqualified workers have the greatest proportion among returners in Estonia and Latvia.

According to the parameter of yearly inflow of cash remittance in dollars, we may say that it became important when the Baltic countries joined the European Union. Therefore, the migrants economically support compatriots in the native country. The comparisons show that in 2005 inflow in Estonia was double less in comparison to Lithuania. According to data from the second decade in the $21^{\text {st }}$ century, inflow to Estonia was increased for more than 1,5 time, but in comparison with Lithuania was 4,8 times less (Table 1). However, Kahanec \& Zimmermann (2016) write about positive roll of remittances on improvement of standard of living in the Baltic countries, especially in Estonia. Households had less financial difficulties if their family members worked abroad.

If the values sent per migrant are considered, it is concluded that the Lithuanians take care the most about their families and homeland. They succeeded to have five times higher inflows (5,24 times - from 2,518 to 13,216 Dollars) between two last censuses. The Latvians have three times higher inflows (2,96 times) while the Estonians almost have doubled their inflows $(1,83$ times).

\section{Conclusion}

Political and economic situation influenced population trends of the Baltic countries with different intensity. Value of their variables of population policy and demographic indicators are similar. Lithuania stands outwith the greatest number and density of inhabitants, but with the lowest share of urban population. Before joining the European Union, only Lithuaniahadincrease in number of inhabitants. Political changes did not have significant influence on the percentageof the oldest and the youngest inhabitants in the Baltic countries. The shares of the oldest inhabitants are growing but the shares of the youngest inhabitants are getting smaller. However, the values of expected duration of life grow since the time of getting independency and projections show that such trend is expected till the end of the $21^{\text {st }}$ century. Last data show that the values of total fertility in Latvia and Estonia are returned on the level which they have had 
after getting the independency while the Lithuanians made the efforts about it but the values are still not achieved. It should be emphasized that the United Nations predict for the years 2050 and 2100 minimum growth of total fertility in the Baltic countries. It cannot significantly change the existing trends, but it represents the hope in the fight for survival and keeping the inhabitants in the Baltic countries which is yet to come.

\section{References}

Пенев, Г. Д. (1995). Становништво по старости и полу. у: Становништво и домаћинства СР Југославије према попису 1991. године. Београд: Савезни завод за статистику, 47: 117-144.

Bowring, B. (2015). The Strasbourg Court and Baltic Ethnopolitics: The Decisive Role of History and Demographics. Etnograficheskoye Obozreniye (Ethnographic Review) 1: 169-171

European Council (2014). The European Union Facts and Figures. General Secretariat of the Council, Bruxelles, Belgique.

Dixon, M. and J. Margo (2006). Population politics. Institute for Public Policy Research.

Đurđev, B. S. (2004). How many children does Serbia need? Stanovnistvo, 42(1-4): 29-44.

Galgóczi, B. and J. Leschke (2016). EU labour migration in troubled times: skills mismatch, return and policy responses. Routledge.

Hiden, J. and P. Salmon (2014). The Baltic nations and Europe: Estonia, Latvia and Lithuania in the twentieth century. Routledge.

Hazans, M. (2016). Migration experience of the Baltic countries in the context of economic crisis. In: Labor Migration, EU Enlargement, and the Great Recession. Berlin-Heidelberg: Springer, 297-344.

Kahanec, M. and K. F. Zimmermann (2016). EU post-enlargement migration and the Great Recession: lessons and policy implications. In: Labor Migration, EU Enlargement, and the Great Recession. Springer, Berlin, Heidelberg, 419-445.

Kalēja, J. and I. Mileiko (2016). Performing Aging in Post-Soviet Latvia. Anthropology of East Europe Review 34(1): 54-72.

Kazlauskiene, E., R. Žitkiené, O. Grižene Rakauskienè, and O. Ranceva (2015). Demographics in quality of life assessment: Lithuania in EU context. Ensuring Sustainable Development in The Period After the Financial Crisis, KSI Transactions on Knowledge Society 7(4): 18-22.

Lane, T. (2014). Lithuania: stepping westward. Routledge.

Lanzieri, G. (2012). Merging populations - A look at marriages with foreign-born persons in European countries. EUROSTAT. Statistics in Focus 29: 1-4. 
Marcu, M. (2011). Population grows in twenty EU Member States. Population 1.

Melnikas, B. (2008). Integration processes in the Baltic region: the new form of regional transformations in the European Union. Engineering economics 60(5): 54-65.

Puur, A., L., Leppik and M., Klesment (2015). Changes in pension take-up and retirement in the context of increasing the pension age: the case of Estonia in the 2000s. Post-Communist Economies 27(4): 497-516.

Rajevska, O. (2015). Sustainability of pension systems in the Baltic States. Entrepreneurial Business and Economics Review 3(4): 139-153.

Smith, G. (Ed.) (2016). The Baltic states: The national self-determination of Estonia, Latvia and Lithuania. Springer.

Šabić, D. and Vujadinović, S. (2014). Regional geography of Europe. University of Belgrade, Faculty of Geography, Belgrade.

Šabić, D. and Vujadinović, S. (2017). Regional development and Regional Policy. Collection of the Papers University of Belgrade Faculty of Geography, LXV: 1a.

United Nations (2013).World population policies 2013, ST/ESA/SER.A/341, Department of Economic and Social Affairs, Population Division, New York.

United Nations (2015). World Population Prospects The 2015 Revision, Key Findings and Advance Tables, ESA/P/WP.241, Department of Economic and Social Affairs, Population Division, New York.

Vujadinović, S. and Šabić, D. (2017). The Importance of Regions in Geographical Research. Collection of the Papers University of Belgrade Faculty of Geography, LXV: 1 a.

\section{Electronic sources}

Creighton, H. (2014). Europe's ageing demography, ILC-UK2014EU Factpack. Available at: https://ilcuk.org.uk/europes-ageing-demography-an-ilc-uk-2014eu-factpack/. Accessed: 28.11.2018.

OECD Pensions Outlook (2012). Available at: http://www.oecd.org/pensions/ Highlights-2016-Pensions-Outlook.pdf. Accessed: 28.11.2018.

World Bank (2018). Urban population (\% in total), All Countries and Economies, The World Bank, Available at: https:// data.worldbank.org/indicator/SP.URB. TOTL.IN.ZS. Accessed: 1.12.2018. 